\title{
Forest fire and law: an analysis of Turkish forest fire legislation based on Food and Agriculture Organization criteria
}

\author{
Osman Devrim Elvan ${ }^{{ }^{*}}$ (D), Üstüner Birben², Ulaş Yunus Özkan ${ }^{1}$, Hasan Tezcan Yıldırım and Yavuz Özhan Türker ${ }^{3}$
}

\begin{abstract}
Background: Because of climate and forest vegetation, Turkey has regions (particularly the Mediterranean and Aegean regions) that are vulnerable to forest fires. Approximately 2000 forest fires have occurred every year for the last 20 years, with at least $48 \%$ of them caused by humans. This percentage increases to $71 \%$ when the rates of fires of unknown causes are included. In this study, legislation on Turkish forest fires was analyzed based on the Food and Agriculture Organization's (FAO's) guide, "Forest Fires and the Law." The guide was prepared by expert lawyers and addresses the basic topics of definitions; institutional setup and interinstitutional coordination planning, monitoring, and assessment; prevention and preparedness; detection and early warning and suppression; participatory and community-based approaches to fire management; fire use; rehabilitation; and law enforcement. The objective of this study was to reveal the current status of Turkish forestry legislation and its practices based on the FAO guide.

Results: According to our analysis, Turkish forestry legislation has followed the FAO criteria $78.1 \%$ of the time. It is clear that effective regulations exist, with the Turkish Constitution being the foremost touchstone. The results illustrate that, no matter how strong the legislation is, a deficiency in administrative measures and a lack of public awareness make combating forest fires unsuccessful.
\end{abstract}

Conclusions: The areas that need to be improved have been determined to be definitions, participatory and community-based approaches to fire management, and creating a fire line. A focus on public participation and the social approach is needed.

Keywords: FAO, forest fire, legislation, Turkey

\section{Resumen}

Antecedentes: Debido al clima y vegetación forestal, Turquía tiene regiones (particularmente la Mediterránea y Egea), que son vulnerables a los incendios forestales. Cerca de 2000 incendios forestales han ocurrido cada año durante los últimos 20 años, de los cuales al menos el 48\% fueron causados por humanos. Este porcentaje se incrementa al 71\% cuando se incluye la tasa de incendios por causas desconocidas. En este estudio, la legislación de Turquía sobre incendios forestales fue analizada basados en la guía de la FAO "Fuegos Forestales y la Ley." Esta (Continued on next page)

\footnotetext{
* Correspondence: elvan40@istanbul.edu.tr

${ }^{1}$ Faculty of Forestry, İstanbul University-Cerrahpaşa, Sarıyer, 34473 Istanbul,

Turkey

Full list of author information is available at the end of the article
} 
(Continued from previous page)

guía fue preparada por abogados expertos y aborda los tópicos básicos sobre definiciones, el contexto institucional, la coordinación del planeamiento, el monitoreo y evaluación, la prevención y preparación, la detección, el alerta temprana y la supresión, la participación y enfoque comunitario del manejo del fuego, el uso del fuego, la rehabilitación, y el cumplimiento de la ley. El objetivo de este estudio fue develar el status actual de la legislación forestal de Turquía y sus prácticas basados en la guía de la FAO.

Resultados: De acuerdo a nuestro análisis, la legislación forestal turca ha seguido los criterios de la FAO en el 78, $1 \%$ de los casos. Queda claro que existen regulaciones, con la constitución turca como su piedra angular más importante. Los resultados ilustran que, sin importar la fortaleza de la legislación, las deficiencias en las medidas administrativas y la falta de conciencia pública hacen poco exitoso el combate de los incendios.

Conclusiones: Se ha determinado que las áreas que necesitan ser mejoradas son las definiciones, la participación y el enfoque comunitario en el manejo del fuego, y la creación de líneas de fuego. Para ello es necesario focalizar la atención en la participación pública y en el acercamiento social.

\section{Abbreviations}

FAO: Food and Agriculture Organization

SWOT: Strengths, Weaknesses, Opportunities, and Threats

\section{Background}

Forest crimes are crimes not subject to any kind of remission under Turkish law (i.e., no general or special amnesty can be granted), as observed in the Turkish Constitution of 1982 and in current Forest Law No. 6831 enacted in 1956 (Ayanoğlu and Güneş 2003). The third paragraph of Article 169 of the Turkish Constitution (Mestav 2009) states that neither particular nor general remission shall be granted for all types of forest crimes. The crimes of setting forests on fire and destroying or thinning forests are also not included within the scope of particular and general remissions. It is stated in the last paragraph of Article 83 of Forest Law No. 6831 (Özkepir and Küçükbiçakçi 2019) that cases related to forest crimes shall be deemed "urgent" by the courts. Pursuant to their urgent characteristics, cases related to forest crimes are heard even during a judiciary recess; legal periods run during the judiciary recess, and notifications made during a judiciary recess are considered valid. Under Turkish law, public prosecutors are obliged to file a case immediately for a complaint made by the Forest Administration regarding a forest crime (Günay 2001).

Conifer forests cover large areas throughout the Mediterranean Basin and are of great ecological and economic importance (Boydak 2004; Urker et al. 2018). Sixty-one percent of the total forest assets of Turkey (21 $678.134 \mathrm{ha}$ ) consists of coniferous species. The risk of forest fires in the regions where conifer species (especially Pinus brutia Ten., Pinus nigra Arnold ssp. pallasiana [Lamb.] Holmboe, and Pinus pinea L.) are located increases during the summer and on windy days (Avcr et al. 2010; Avcl and Boz 2017). In some years, high seasonal temperatures and winds cause serious fires. Forest fires that occurred in the Serik district of Antalya province in
2008, where 15795 ha of forest burned, lasted for several days before they were controlled; this was due to the forest's composition being Calabrian pines ( $P$. brutia) and the high wind speeds in the area at the time. This fire was the largest forest fire ever recorded in Turkey (Çoban and Eker 2010; Avc1 et al. 2016).

Forest fires have become one of the major threats to living conditions in many countries (Covington and Moore 1994; Wotawa and Trainer 2000; Hessburg et al. 2005; Tedim et al. 2015). It is widely accepted that a significant percentage of these fires are caused by humans (Jaiswal et al. 2002; Karki 2002; Stephens 2005; Martínez et al. 2009; Özden et al. 2012; Montiel-Molina 2013). Some countries and cultures, such as India, utilize the vegetation that remains after a forest fire, especially firewood, as a source of income, (Schmerbeck et al. 2015). Most common causes of forest fires are human activities, such as land clearing (especially for shifting cultivation, other agricultural activities, and the maintenance of grasslands for livestock management), extraction of nonwood forest products, industrial development, resettlement, and hunting; negligence and arson are also human causes (Morgera 2010).

Studying the effects of forest fires on both ecosystems and societies, the Food and Agriculture Organization (FAO) has highlighted the significance of human factors in forest fires. The organization published a guide titled, "Forest Fires and the Law: a Guide for National Drafters Based on the Fire Management Voluntary Guidelines," in 2009. In the guide, the FAO analyzed the legislation and management of the members of the European Union and other countries (Senegal, Argentina, Indonesia, Russian Federation, United States of America). The starting point and objective of the FAO study are described as follows:

The study starts with an overview of the key concepts related to fire management in general and forest fire management specifically. It highlights the links 
between forest fires and the attainment of the goals of international environmental agreements. It also briefly illustrates the role of legislation in supporting a holistic concept of forest fire management as well as the benefits of participatory approaches to legal analysis and development. The study addresses some general legal questions: how forest fire legislation is structured and how it relates to the broader legal framework in a country, coupled with an overview of a sample of countries' legal approaches on forest fires. The central part of the study proceeds on a thematic basis, comparing legal solutions related specifically to: opening provisions (definitions, objectives and scope of application); institutional setup and coordination; planning, monitoring and assessment, including issues of public participation in decision making; prevention and suppression; controlled use of fire; participatory and community-based approaches; rehabilitation; and questions of law enforcement. Concluding remarks highlight the strengths and weaknesses of the legislation analyzed and identify priority legal issues and approaches to guide national legislators and forest managers."

Our study analyzed Turkish forestry legislation and management holistically in consideration of the FAO guide, the objective of which is summarized above, and also, to reveal to what extent these efforts must be enhanced. For this purpose, the vulnerability and status of Turkey in terms of forest fires was briefly explained and then the legislation relating to forest fires was presented. Based on these findings, eight criteria stated in the FAO guide were explored in terms of related Turkish legislation and practices.

\section{Methods}

This study's main purpose was to compare Turkish forestry legislation and practices with those in the FAO guide for a clear analysis (Table 1). The FAO guide was prepared in 2009 according to international conventions that determine principles on forest fires, as well as to the legislation of countries grouped by the FAO according to geographical regions. The guide frames the kinds of regulations that should be developed in terms of management and legislation concerning forest fires (Morgera and Cirelli 2009).

In Turkey, all forests are under the supervision and responsibility of the State. The management of forests is carried out by the General Directorate of Forestry (OGM) in affiliation with the Ministry of Agriculture and Forestry. The OGM is responsible for dealing with and combating forest fires with its 28 district offices, 243 forestry departments, and 1403 forest sub-district directorates (MOAF 2019, TOD 2019). Forest sub-district directorates report the number of fires and burned forest areas and every year to the directorates with which they are affiliated. Forest sub-district directorates also keep minutes regarding the causes of forest fires and these minutes are published by OGM both in its activity reports and on their website (https://www.ogm.gov.tr).

In the guide, the number of crimes and the amount of burned area were published on the OGM website (https://www.ogm.gov.tr), and as activity reports of the OGM, graphed by years. In addition, the causes of forest fires were reported by chiefs of forest management and published in the activity reports of OGM on the website. If there is a forest fire caused by a crime, forest subdistrict directorates must take the necessary actions to file a lawsuit due to the mandatory provisions of forestry legislation. Reports related to lawsuits were also published in OGM activity reports and on their website (https://www.ogm.gov.tr/tr/faaliyet-raporu), under the title "the reasons for the forest crime." Data containing number of forest fires, amount of burned forest area, and crime statistics reported by the 1403 chief officers were also published by OGM.

Data were gathered for the period of 2013 to 2018 in terms of forest fire and arson. The years 2013 to 2018 were chosen because the data were complete during this period. In terms of the amount of burned area and the number of fires, the data between 1998 and 2018 were compiled by years.

We used a five-point scoring chart, previously used by Aydin Coşkun and Gençay (2011), Elvan (2013), Elvan and Turker (2014), Elvan et al. (2020), and Elvan and Birben (2021), to rate how well Turkish management practices compared with the FAO guide. Positive or adverse effect and adequacy of the relevant provision of forestry legislation (Article 169 of the Turkish Constitution of 1982; Forest Law No. 6831; Regulation Regarding Compensation Payable to Those Injured and Killed During Forest Fire Fighting; Regulations for the Duties of Officials Assigned with the Prevention and Extinguishing of Forest Fires; and Notification No. 285 issued by the General Directorate of Forestry) for meeting the criterion were assessed by scoring on a scale from 0 to 4: $0=$ does not include any provision or practice; 1 = includes very narrow provision or practice and is insufficient; 2 = includes an indirect provision or practice but is not sufficient; $3=$ includes a positive, indirect provision or practice and is sufficient; $4=$ includes a positive, direct provision or practice and is sufficient.

Eight criteria were considered in this study: (1) Definitions; (2) Organizational structure and coordination among organizations; (3) Planning, monitoring, and evaluation", (4) Prevention and preparedness, scanning, early warning, and suppression; (5) Participation and social approach to fire management; (6) Creating a fire line; (7) Rehabilitation; and (8) Enforcement. A score of 0 to 4, shown 
Table 1 Scoring of Turkish legislation on how well it meets Food and Agriculture Organization (FAO) guidelines on legal and regulatory frameworks related to forest fires, as the result of our review of Turkish legal regulations and administrative practices, in 2019. Scoring was done on a scale of 0 to 4: $0=$ does not include any provision or practice; $1=$ includes very narrow provision or practice and is insufficient; 2 =includes an indirect provision or practice but is not sufficient; 3 = includes a positive, indirect provision or practice and is sufficient; $4=$ includes a positive, direct provision or practice and is sufficient

\section{FAO criterion}

Explanation Turkish practices for meeting criterion

Definitions

Clarity of basic definitions and technical terms related to forest fires and their inclusion in legislative texts

- No specific law regarding definitions relating to forest fires has been enacted in Turkish legislation. Forest Law No. 6831 from 1956 (Ayanoğlu and Güneş 2003) includes some definitions about which lands are to be regarded as forestlands. It does not have specific definitions relating to forest fires.

- A few definitions are found in the "Regulation Regarding Compensation Payable to Those Injured and Killed During Forest Fire Fighting" of 2004 (Bayındır 2016). The definitions are about compensation, forest-fire fighting, and disability levels. Therefore, it can be concluded that there are no satisfactory definitions concerning forest fires in the regulations.

- Notification No. 285 (Mestav 2009), which deals with practices, includes a few more definitions. Notifications are about the written sources that follow regulations within the legislation hierarchy. Notification No. 285 was issued by the General Directorate of Forestry. The Forest Administration is authorized to make changes according to the situation. In this notification, the term forest fire has been described and types of forest fires have been explained. The notification explains the causes of fire in detail, methods to be followed during firefighting, and the planning and organization needed during fire extinguishing.

\section{Organizational structure and coordination among organizations}

The coordination among organizations concerned with fighting forest fires

- The General Directorate of Forestry (OGM) is the institution responsible for dealing with forest fires in all regions of Turkey. The Department of Forest Fire Combating works under OGM. It has 28 district offices, 243 forestry departments, and 1403 forest sub-district directorates that are responsible for combating fires. Each forestry department is equipped with enough fire engines, tools, helicopters, and planes to manage fires during the peak seasons (OGM 2015).

- Under Articles 68 to 71 of Forest Law No. 6831 (Ünal 2010) regarding mail, communication, and transportation organization, the constabulary of internal affairs and the governors of the provinces are responsible for coordinating and providing services for firefighting. For instance, the law states that provisions for the "Regulations for the Duties of Officials Assigned with the Prevention and Extinguishing of Forest Fires" shall be executed by the Ministries of National Defense, Internal Affairs, Communications, and Forestry.

\section{Planning, monitoring, and evaluation}

The establishment of fire management centers and necessary pre-fire and post-fire planning, monitoring, and evaluation processes during the seasons when forest fires peak

- Complete 24-hour surveillance is carried out by observers in 776 watchtowers to detect forest fires and notify response teams as soon as possible.

- Article 75 of the Forest Law (Mestav 2009) states that providing watchtowers, communication systems, and other equipment for combating forest fires is obligatory and setting a budget for those purposes is also obligatory.

- Notification No. 285 outlines regulations on planning for and operating watchtowers.

- The General Directorate of Meteorological Services shares data on weather conditions, temperature, wind direction, and wind speed as they relate to fire hazards and activities. The directorate also provides information on the most common times of day at which forest fires break out.

\section{Prevention and preparedness, scanning, early warning, and suppression}

The prevention, prohibition, or limitation of flammable elements and activities that may cause fires; regulations on preparedness for forest fires that occur in spite of precautions; methods for suppressing fires; provisions for scanning; and the establishment of the technological infrastructure that provides early warnings for the sake of an immediate response

- Article 76 of Forest Law No. 6831 (Ünal 2010) forbids the lighting of fires in forests except in permitted areas, and also forbids the dropping of flammable materials and live cigarettes in forests. As per Article 110 of the Forest Law (Ünal 2010), the penalty for these acts is imprisonment from one to three years.

- Article 75 of the Forest Law states that providing communication systems and other equipment for combating forest fires is obligatory, and setting a budget for this purpose is also obligatory.

- The OGM has established, under the authority granted it by the Law, a Forest Fire Early Warning and Management System (considered among the best projects by the public in 2005). The system locates rising smoke within 15 seconds after a fire starts and forwards the data to the Fire Operations Center. Response teams then decide whether to try to extinguish the fire by land or air after considering geographical features (www.ogm.gov.tr). The software for this purpose was developed with the support of TUBITAK (the Scientific and Technological Research Council of Turkey) and has been sold to many countries, such as the United States of America, Italy, Greece, and Tunisia, and is still in use (www.tubitak.gov.tr). 
Table 1 Scoring of Turkish legislation on how well it meets Food and Agriculture Organization (FAO) guidelines on legal and regulatory frameworks related to forest fires, as the result of our review of Turkish legal regulations and administrative practices, in 2019. Scoring was done on a scale of 0 to 4: $0=$ does not include any provision or practice; $1=$ includes very narrow provision or practice and is insufficient; 2 =includes an indirect provision or practice but is not sufficient; 3 = includes a positive, indirect provision or practice and is sufficient; $4=$ includes a positive, direct provision or practice and is sufficient (Continued)

\title{
FAO criterion
}

Explanation Turkish practices for meeting criterion

Public participation and social approach to fire management

Because forest fires may have a direct influence on living conditions, especially in regions where the public lives in close proximity to them, provisions are offered about public participation in fire prevention and raising the consciousness of the public about the issue.

- As in the general environmental issue, Turkish legislation alone is not enough to connect the public with the issues concerning forest fire prevention and impacts. The Regulation Regarding Compensation Payable to Those Injured and Killed during Forest Fire Fighting (Bayındır 2016) is active, as well. Notification No. 285 also includes regulations about those who are to participate in forest-fire fighting and states that catering for the participants shall be provided by the Forest Administration.

\section{Creating a fire line}

Regulations regarding the circumstances for and method of creating a fire line as a means of fire suppression

- Creation of a fire line, or counterfire, is only regulated by Notification No. 285. It is only done by a fire warden or a craft authorized by a fire warden due to the great risk it bears. The goal is to get a forest fire under control before it gets worse by rapidly reducing or completely removing flammable material from the fire's path. Either a counterfire or a gradual counterfire can be implemented. Fire safety roads and firebreaks, forest roads, natural obstacles, and fire-extinguishing lines are all created or utilized. Due to the risk of higher fire severity, the counterfire method is not executed at the back of the hillsides where slope exceeds $20 \%$.

\section{Rehabilitation}

Rehabilitation of forests after a fire and prohibition of their use for other purposes after a fire

- Turkish legislation provides for rehabilitation of these forestlands after forest fire, and strictly prohibits their use for any other 4 purpose, such as agriculture, grazing, or settlement. Primarily, Article 169 of the Turkish Constitution of 1982 (Mestav 2009) orders the reforestation of burned forestlands and prohibits any kind of agricultural or stock-raising activities on these lands. Article 2 of Forest Law No. 6831 (Gençay et al. 2018) states that burned forestlands cannot be regarded as degraded forestlands and authorization to use of the forest purposes outside reforestation cannot be granted for a specific period of time. The penalty for those who commit the crime of occupying forestlands and grazing on burned forestlands is doubled.

\section{Enforcement}

Legal and administrative measures against prohibited acts and the distribution of responsibility for taking necessary precautions during and after any forest fire

\begin{abstract}
- According to the Turkish Constitution, a set of rules related to forest fires must be regulated by law. Thus, law enforcement against forest fires is explained in Forest Law No. 6831 in Articles 68 to 76 and 104 to 107, and in Article 110 (Ünal 2010).

- Accordingly, those conscripted to help fight a fire who do not obey, and those who do not comply with a ban on entering forest areas soon after forest fire or during drought, shall have fines imposed on them. One who does not inform the Forest Administration about a forest fire in spite of witnessing it shall be sentenced to imprisonment of up to six months. Lighting a fire within the borders of a forestland except for in permitted areas, dropping flammable material or live cigarettes, and burning stubble and similar vegetative cover at a distance of less than $4 \mathrm{~km}$ from a forestland shall be subject to imprisonment of one to three years. Causing a forest fire by carelessness shall be subject to imprisonment of two to seven years. Burning forests deliberately shall be subject to imprisonment of a minimum of ten years, and burning forests for terrorist purposes shall be subject to life imprisonment. In addition to the aforementioned penalties, punitive fines shall be imposed. Law No. 6831 refers to the Turkish Penal Code for certain crimes. Civil servants who do not muster for combat shall be sentenced to imprisonment for neglecting their duty. Damaging any vehicle or equipment that belong to the Forest Administration and are used to combat fires shall also be subject to imprisonment for causing damage to property (Elvan 2014).
\end{abstract}

in the last column of the Table 2, indicates how closely Turkish legislation and practices have met the FAO criteria.

In addition to that analysis, a Strengths, Weaknesses, Opportunities, and Threats (SWOT) analysis related to Turkish forestry legislation and its practices has also been provided by using related legislation and strategic plans (for the periods of 2010 to 2014, 2013 to 2017, and 2017 to 2021) and annual activity reports (from 2006 to 2019) of the General Directorate of Forestry (Table 2).

\section{Forest fires in Turkey}

In Turkey, $27.6 \%$ of the total surface area consists of forests. Of these forests, $99.897 \%$ is State (i.e., Turkey) owned, $0.086 \%$ is privately owned, and $0.017 \%$ belongs to public legal entities. According to Article 169 of the Turkish Constitution, the State is responsible for the supervision and conservation of all the aforementioned types of forests. According to the same article, forests that suffer fire should immediately be reforested and neither agricultural nor livestock farming activities should be 
Table 2 Strengths, Weaknesses, Opportunities, and Threats (SWOT) analysis of Turkish legislation and administrative practices related to forest fires from our review in 2019 comparing Turkish legal regulations and administrative practices with the Food and Agriculture Organization (FAO) guide's criteria

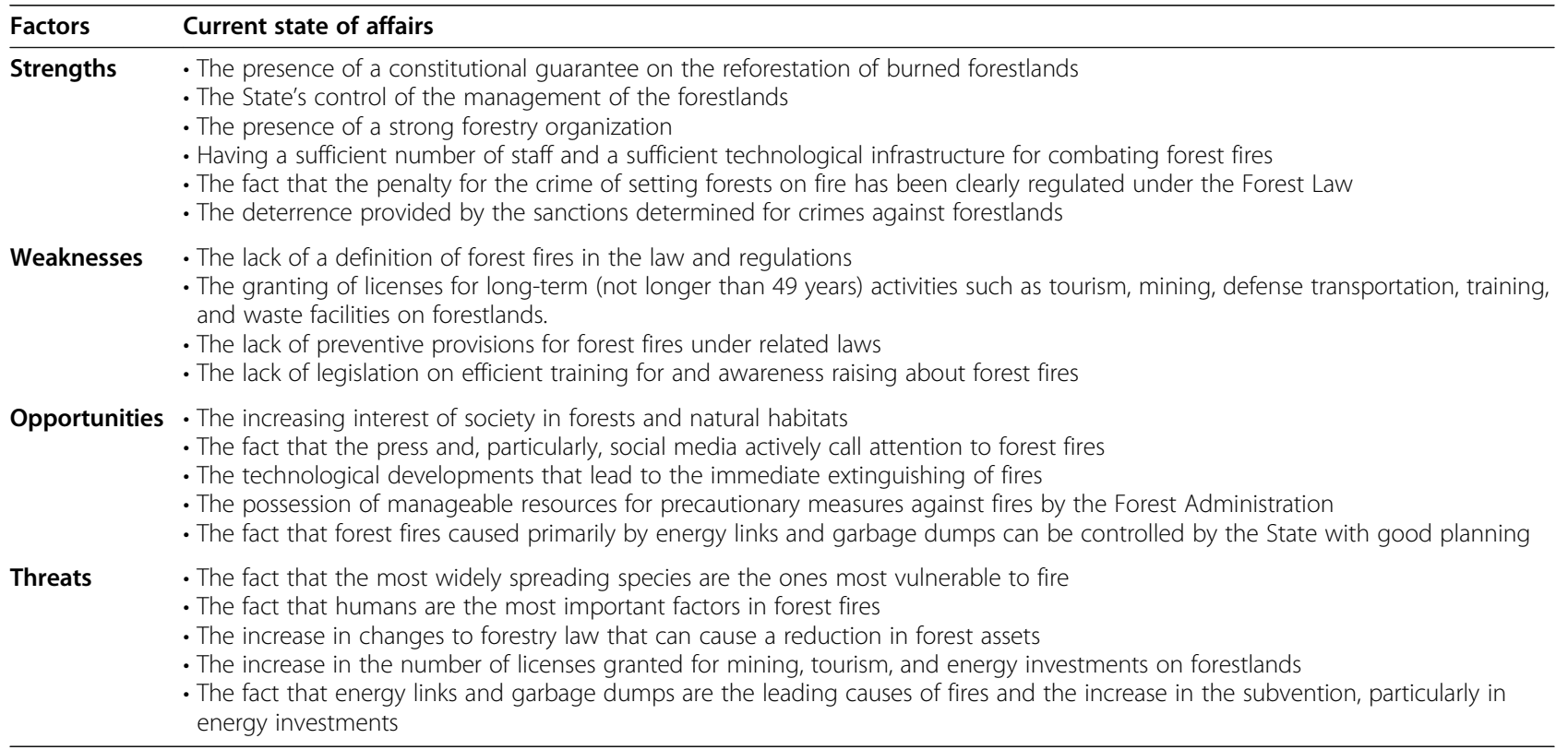

allowed in them. Sixty percent of Turkey's forests contain species that are sensitive to fires (Küçükosmanoğlu et al. 2013). Approximately 12 million hectares of forestland occur near the coastlines of the Mediterranean, Aegean, and Marmara regions, where they sometimes extend up to $160 \mathrm{~km}$ inland, are vulnerable to forest fire. This constitutes approximately $57 \%$ of Turkey's forestlands. The factors affecting and increasing vulnerability of these forests to fire include the presence of fire-prone species, longlasting summer droughts that exceed six months, low relative humidity levels, drying winds, and unfavorable land conditions (OGM 2013). This is illustrated in the forest fire risk map of Turkey, which includes species, the effects of the climate, and the sites of previous forest fires (Fig. 1).

When the data on recent forest fires and the size of the areas affected are examined, it is clear that

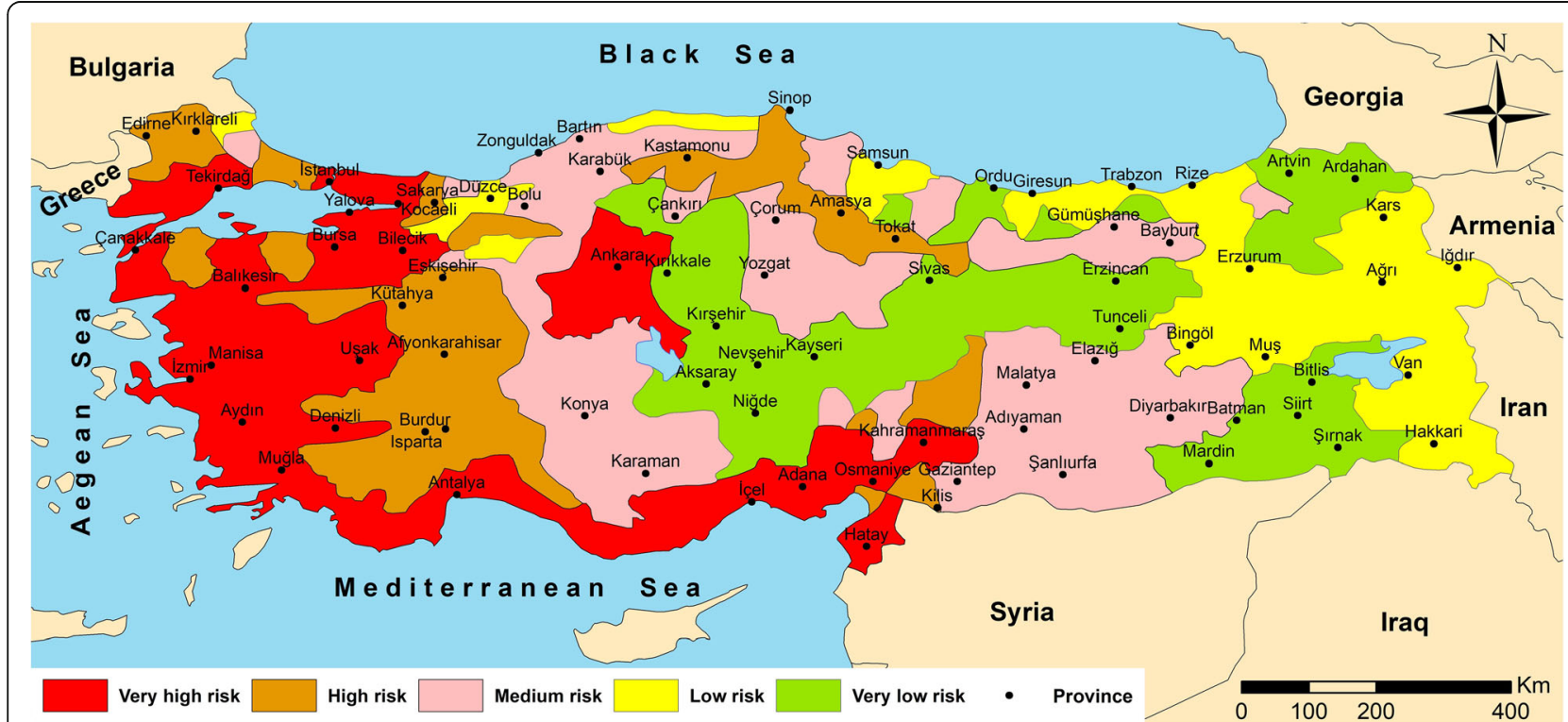

Fig. 1 Forest fire risk map of Turkey. Red areas have the highest fire risk; green areas have the least fire risk. A large part of the forested area in Turkey is under high risk of fire. Map compiled from statistics of the forestry administration, and used in our 2019 review comparing Turkish practices with the Food and Agriculture Organization (FAO) guide's criteria 
approximately 2000 forest fires break out every year; in some years, this number is higher. In 2013 and 2018 this number nearly doubled (Figs. 2 and 3).

A significant number of forest fires is attributed to unknown origin. One of the main reasons for this situation is the changes in forest law regarding forest ownership and utilization. These legal changes allow for activities that increase deforestation. The increase in forest crime gains momentum with the initiation of such legal regulations and with society's awareness of such legal processes (Elvan 2009). For instance, it is possible to state that there is a direct correlation between the law on the sales of degraded forestlands (generally known as $2 / \mathrm{B}$ lands, with a reference to Article 2 of the Forest Law; Gençay et al. 2018) of 2012 and the increasing number of forest fires in 2013. Because the law gives the public the perception that deforestation is possible, forests may be degraded in time with the expectation that the degraded forests can be sold for profit in the future. With the amendments in Forest Law No. 6831 in 2012, previously illegal transhumance activities on forestlands were made legal; lands could be leased or bought for this purpose. The legal periods for the sale of $2 / \mathrm{B}$ areas were extended in 2016 by an amendment. Those who wanted to benefit from this time extension increased their illegal activities (especially illegal expansion into and occupation of these areas) in the forestlands. In brief, the number of forest crimes has increased as a result of the aforementioned amendments and similar ones. Considering this, trust and faith in these laws to protect forests are weakening, and this trend should not be ignored. When the causes of forest fires are examined, it becomes apparent that fires caused by negligence outnumber fires due to other reasons, and the size of the lands affected by these fires is greater over a six-year period (Figs. 4 and 5). Accordingly, it is obvious that public awareness on the proper utilization of forestlands, both commercially and recreationally, should be raised. It is also accurate to state that administrators of forestlands are not taking their work as seriously as they should; this is evident in light of the increased number of forest fires due to unknown causes (Figs. 6 and 7).

Of the four main classifications of fire, forest fires by intention $^{1}$ are classified as being due to arson, deforestation, terrorism, or other reasons. Arson is the leading cause of intentional forest fire (Figs. 8 and 9).

Interviews $^{2}$ with local forest law enforcement units showed that the usual main objective of offenders is to distract security forces while engaging in illegal activities,

${ }^{1}$ In Turkish criminal law, crimes can be committed intentionally or by negligence. Here, "intention" is used to mean deliberate and willful commitment of the crime.

${ }^{2}$ Telephone interviews were made with ten forest management chiefs who were working in Muğla, İzmir, and Antalya. such as theft, drug dealing, and abduction. Another possible reason for arson is to take revenge on the government (especially the Forest Administration) due to a conflict of interest. Deforestation fires occur either for the carrying out of agricultural activities on fertile forestlands or the expansion of agricultural lands that are currently forested. For the purposes of harming the State, causing public fear and panic, or escaping from security forces, terrorist fires are set (MOJ 2020). The crime of setting forests on fire can be committed by negligence according to Forest Law No. 6831. Therefore, forest fires due to negligence have been defined as follows in official records: fires caused by stubble burning, fires on dump sites, fires caused during hunting activities, fires caused by smaller fires lit by shepherds for the purpose of heating, fires started by cigarette stubs, fires caused on picnic sites, fires caused by power lines and electrical transmission systems, fires caused by traffic accidents, and other causes (see Figs. 4 and 5).

In recent years, a significant increase in the number of fires caused by energy transmission lines has occurred. The lines that pass over forestlands can be compromised due to weather conditions, lack of maintenance, insufficient controls, and other reasons (Kucukosmanoglu et al. 2015). Forest managers, power administrators, and subcontractors are frequently prosecuted for crimes against forests due to an increasing number of mine operation permits and associated energy transmission lines for the mines. This situation arises from the deficiencies in planning, maintenance, and control mechanisms. It may also be accurate to state that forest fires caused by stubble burning result from a lack of control on the part of the offenders and also a lack of education and awareness in such people.

\section{Legal resources in Turkish law on forest fires}

Education and the raising of awareness are the most effective ways to prevent or reduce wrongful behaviors (Ayberk 2000; Aguilar and Montiel 2011). Enforcement of laws is also effective. In other words, the restrictions, prohibitions, and sanctions imposed by the legislative power of the State can cause significant changes in human behaviors. Amendments to forest-fire-related legislation that are in line with international conventions and adopted principles have resulted in positive outcomes in terms of combating forest fires (Simorangkir and Sumantri 2002; FAO 2006; Rosenbaum 2007). However, it is necessary to develop not only the legislation but also the most current management techniques (Ganz et al. 2003; Bal et al. 2019). Current techniques and local customs do not reflect the most up-to-date techniques or utilize the latest technology (Ganz et al. 2003; Lampin-Maillet et al. 2009). 


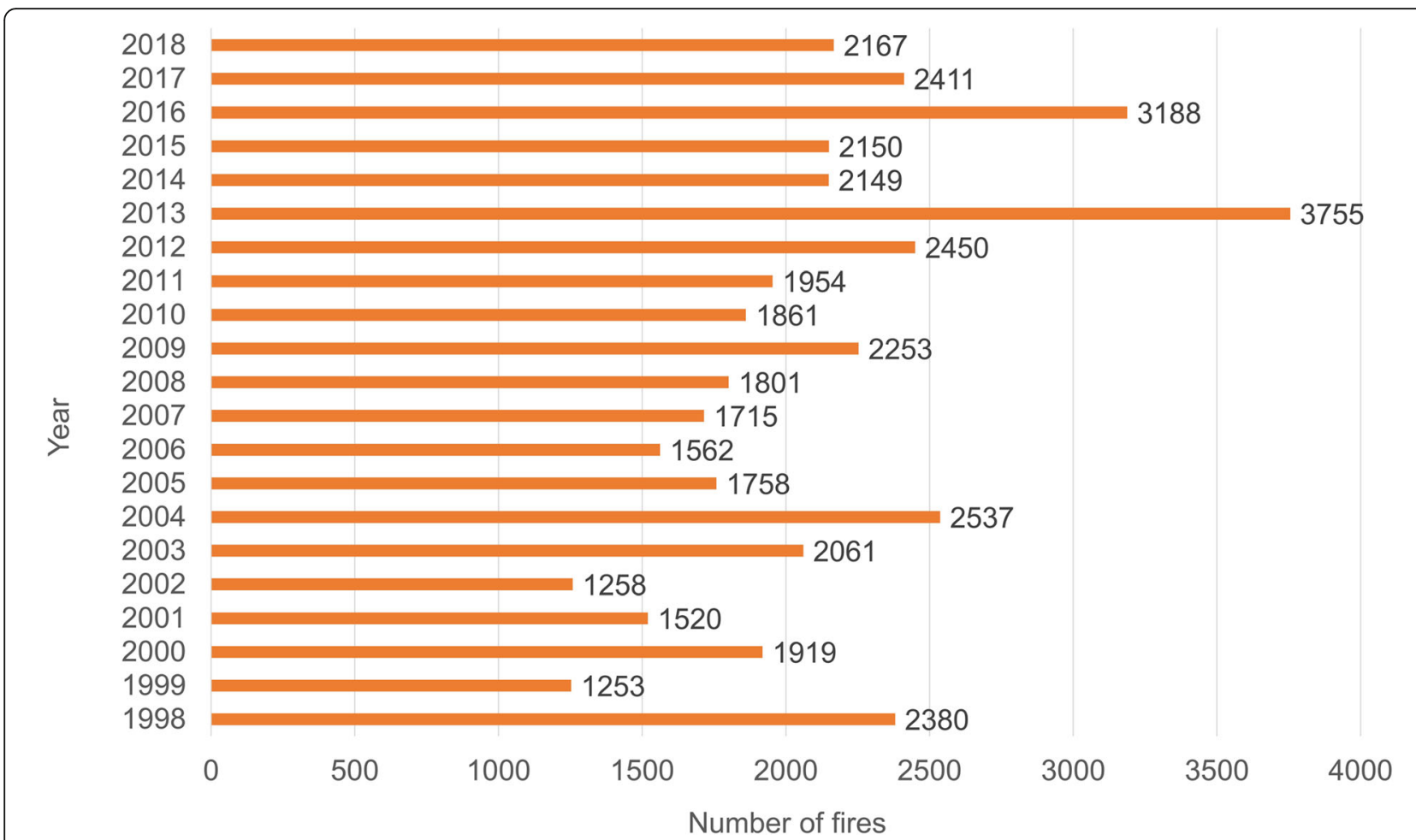

Fig. 2 Distribution of the number of forest fires in Turkey between 1998 and 2008, based on statistics published by the forestry administration, and used in our 2019 review comparing Turkish practices with the Food and Agriculture Organization (FAO) guide's criteria. The number of forest fires in Turkey over the 20-year period does not demonstrate a significant downward trend, indicating that there is a need for more action

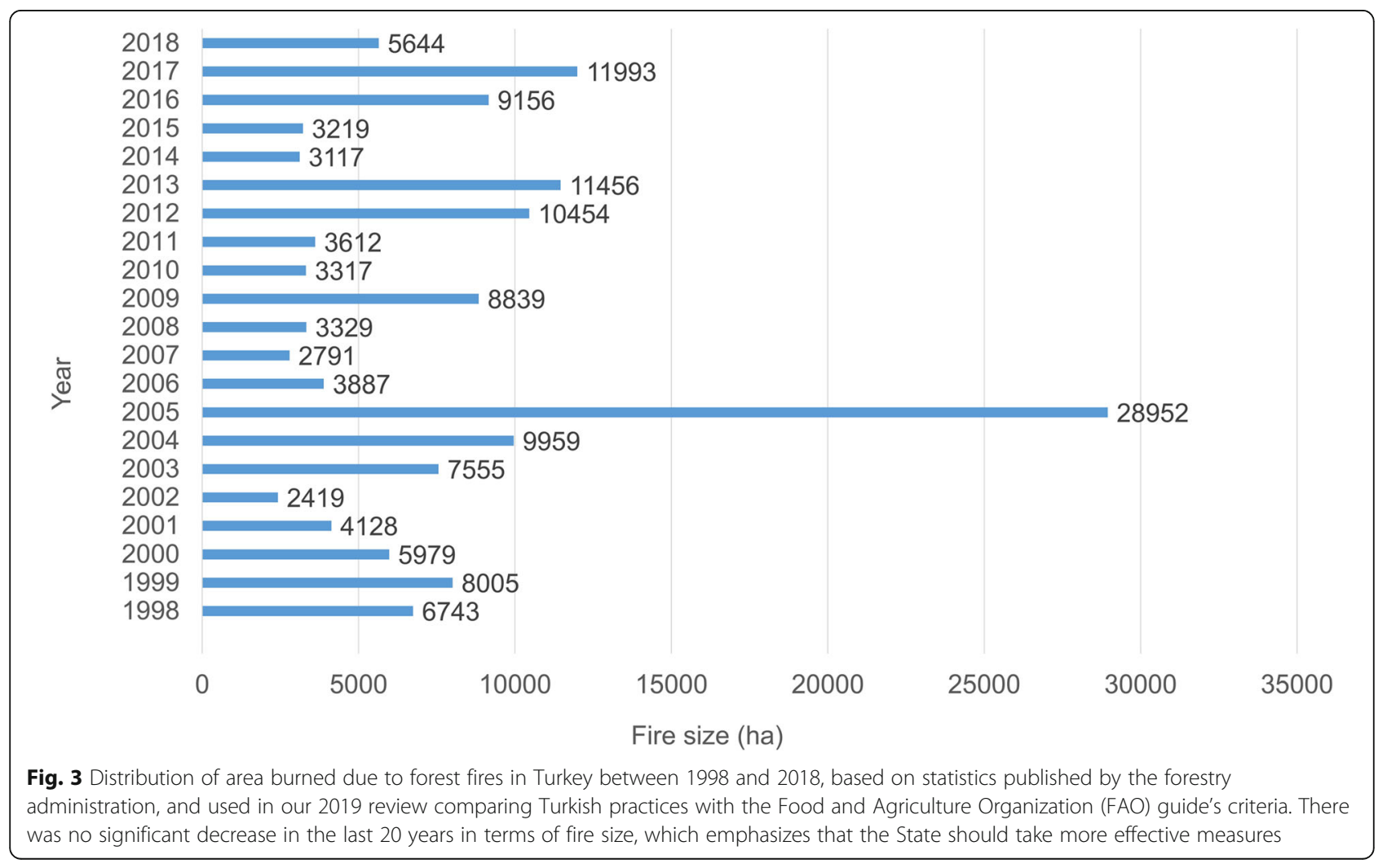




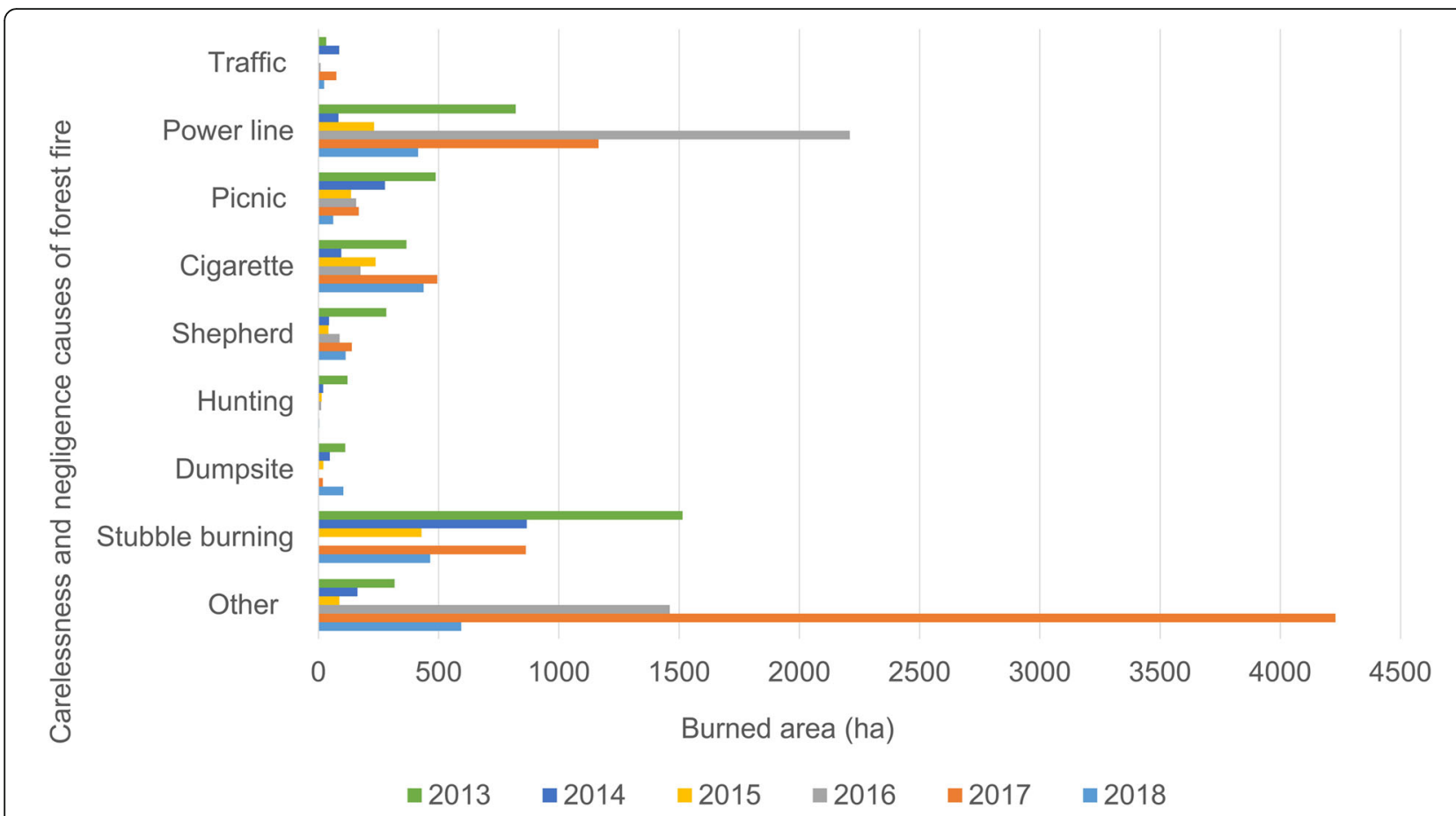

Fig. 4 Area (ha) damaged by forest fires in Turkey that were caused by negligence or carelessness from 2013 to 2018. Data compiled from statistics of the forestry administration, and used in our 2019 review comparing Turkish practices with the Food and Agriculture Organization (FAO) guide's criteria. Note the increase in forest fires caused by power lines

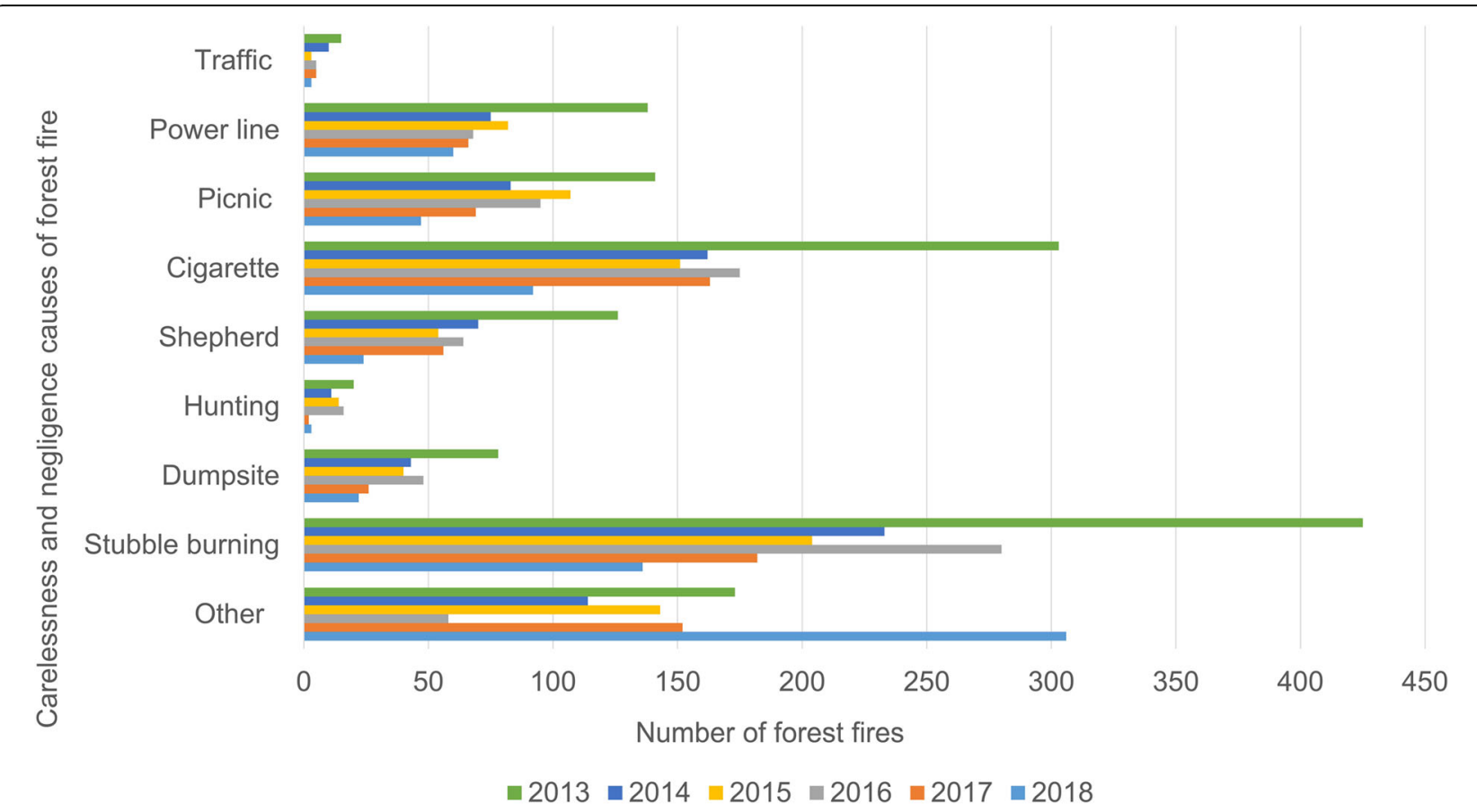

Fig. 5 Number of forest fires in Turkey that were caused by negligence or carelessness from 2013 to 2018. Data compiled from statistics of the forestry administration, and used in our 2019 review comparing Turkish practices with the Food and Agriculture Organization (FAO) guide's criteria. Note the disproportionately large number of forest fire due to cigarettes and stubble burning 


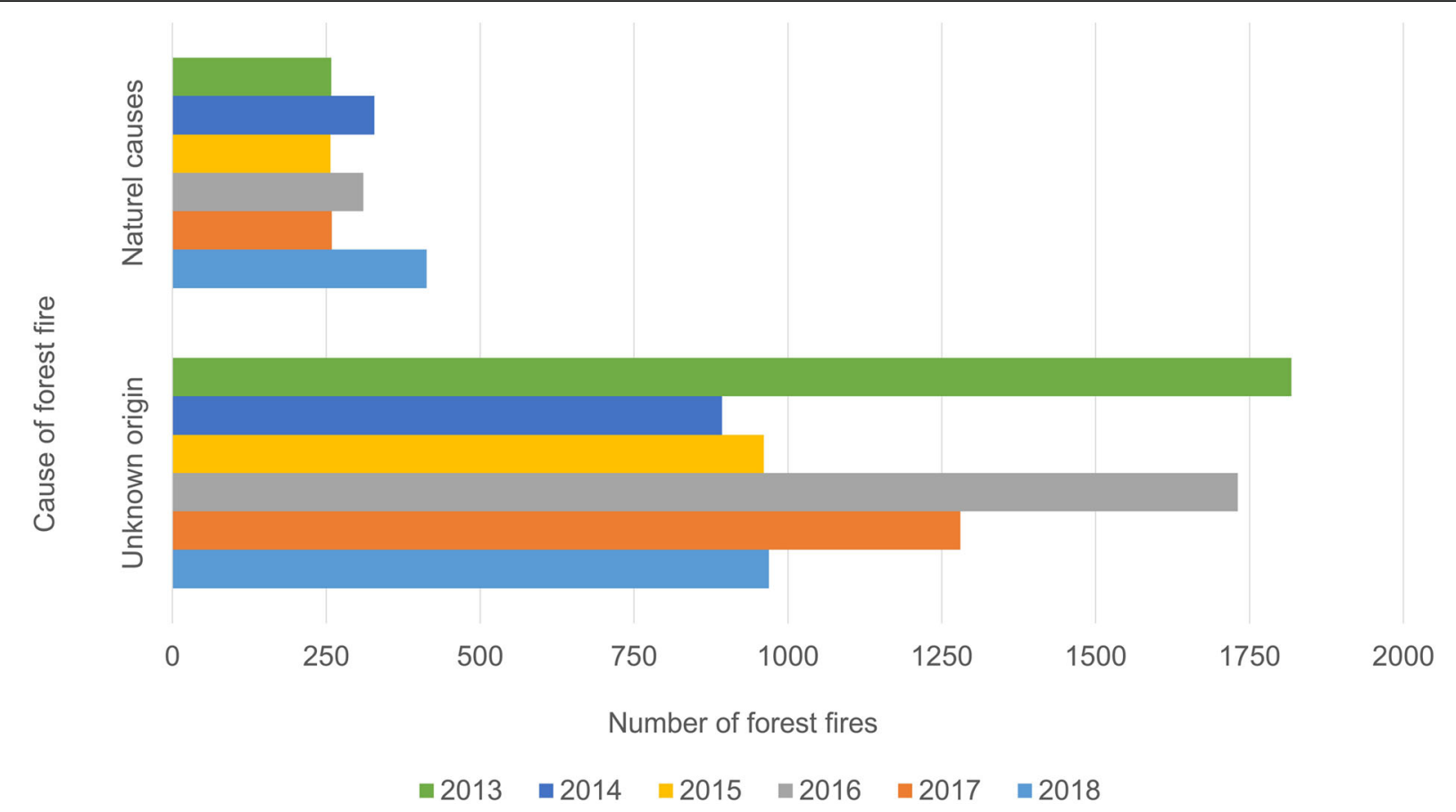

Fig. 6 Number of forest fires in Turkey that started from unknown origin and natural causes from 2013 to 2018. Data compiled from statistics of the forestry administration, and used in our 2019 review comparing Turkish practices with the Food and Agriculture Organization (FAO) guide's criteria. Note the disproportionately large number of forest fires of unknown origin

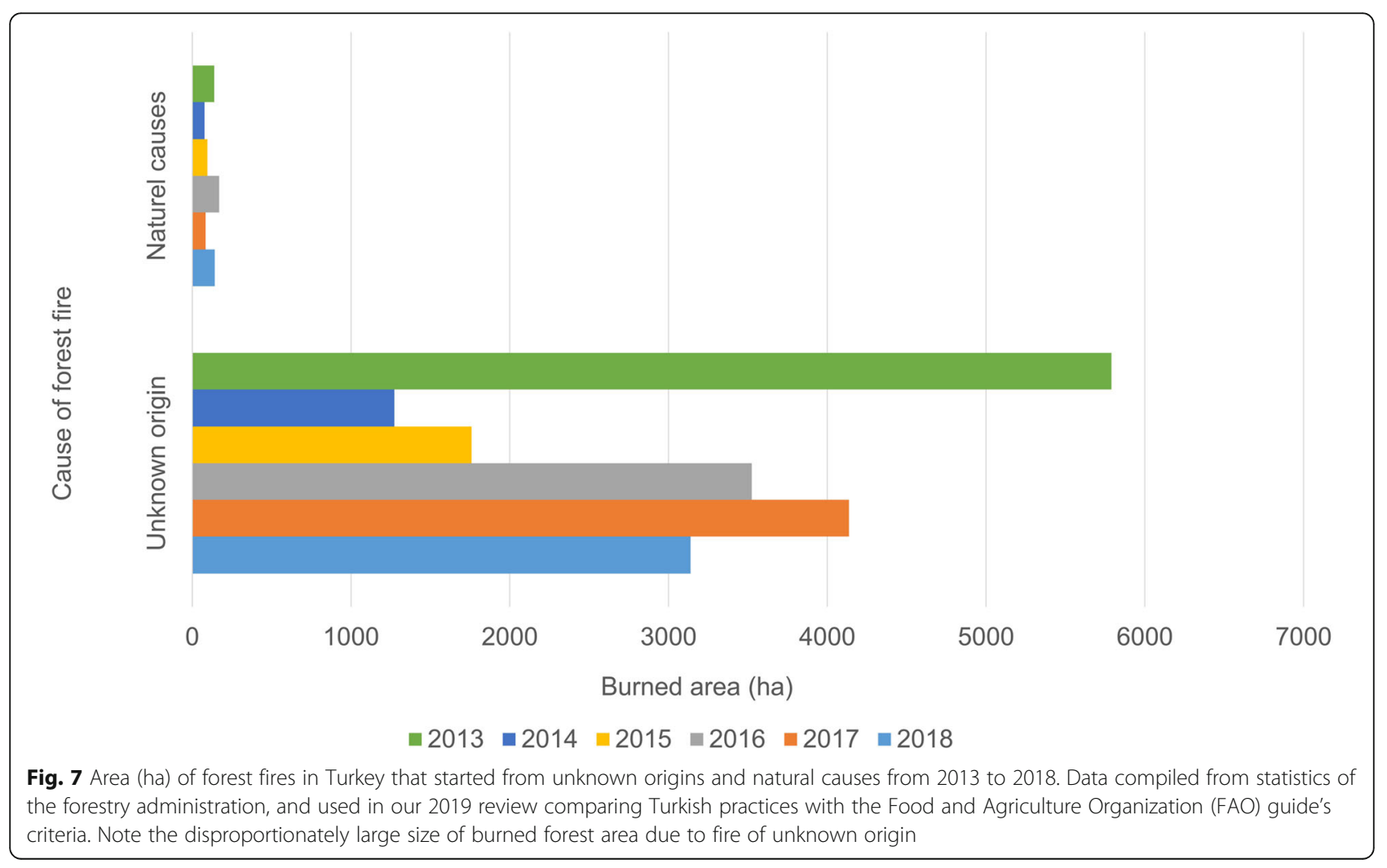




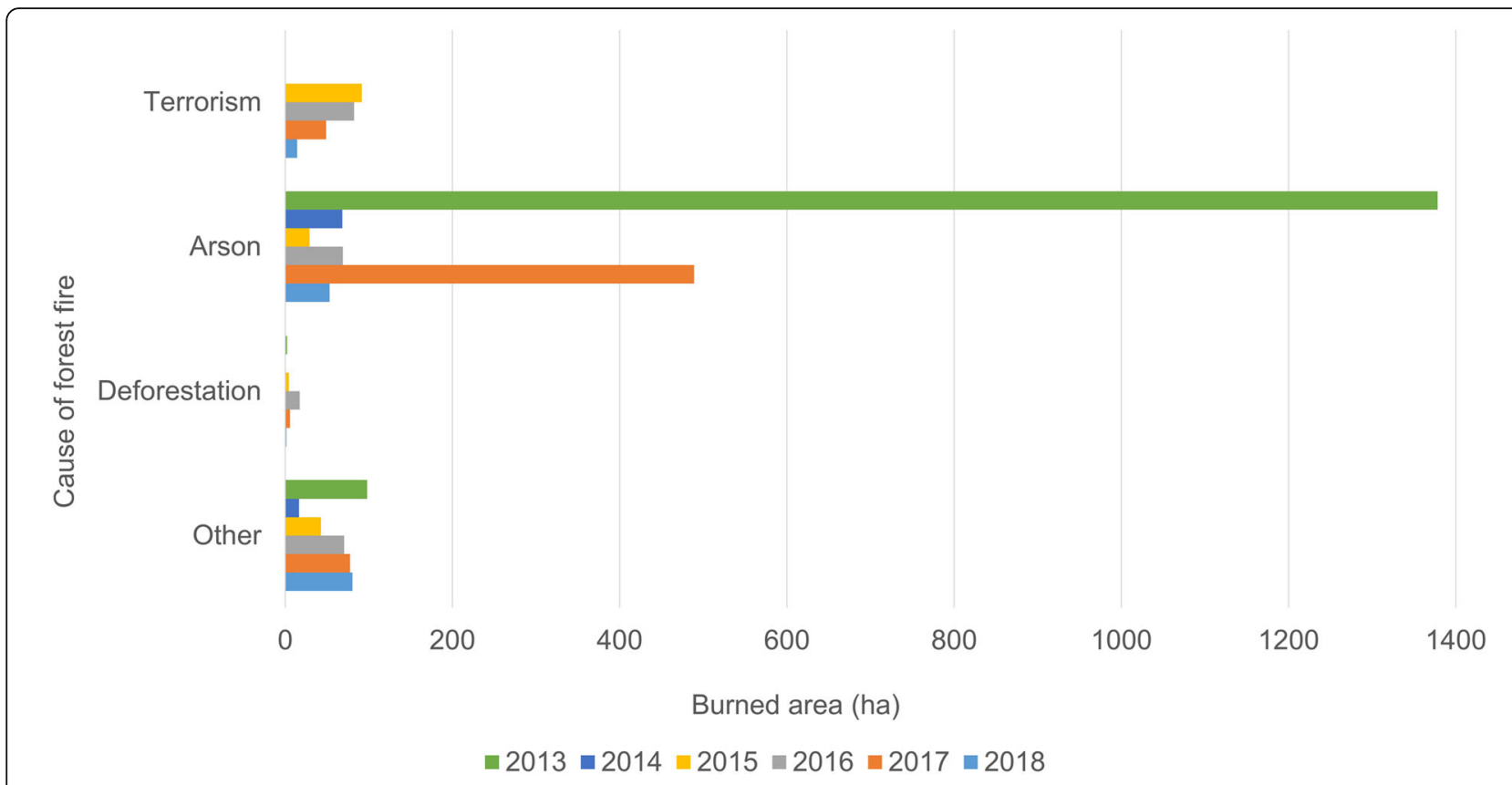

Fig. 8 Area (ha) of Turkish forestlands that were damaged by intentionally set fires between 2013 and 2018. Data compiled from statistics of the forestry administration, and used in our 2019 review comparing Turkish practices with the Food and Agriculture Organization (FAO) guide's criteria. Note the disproportionately large amount of burned forest area attributed to arson and terrorism

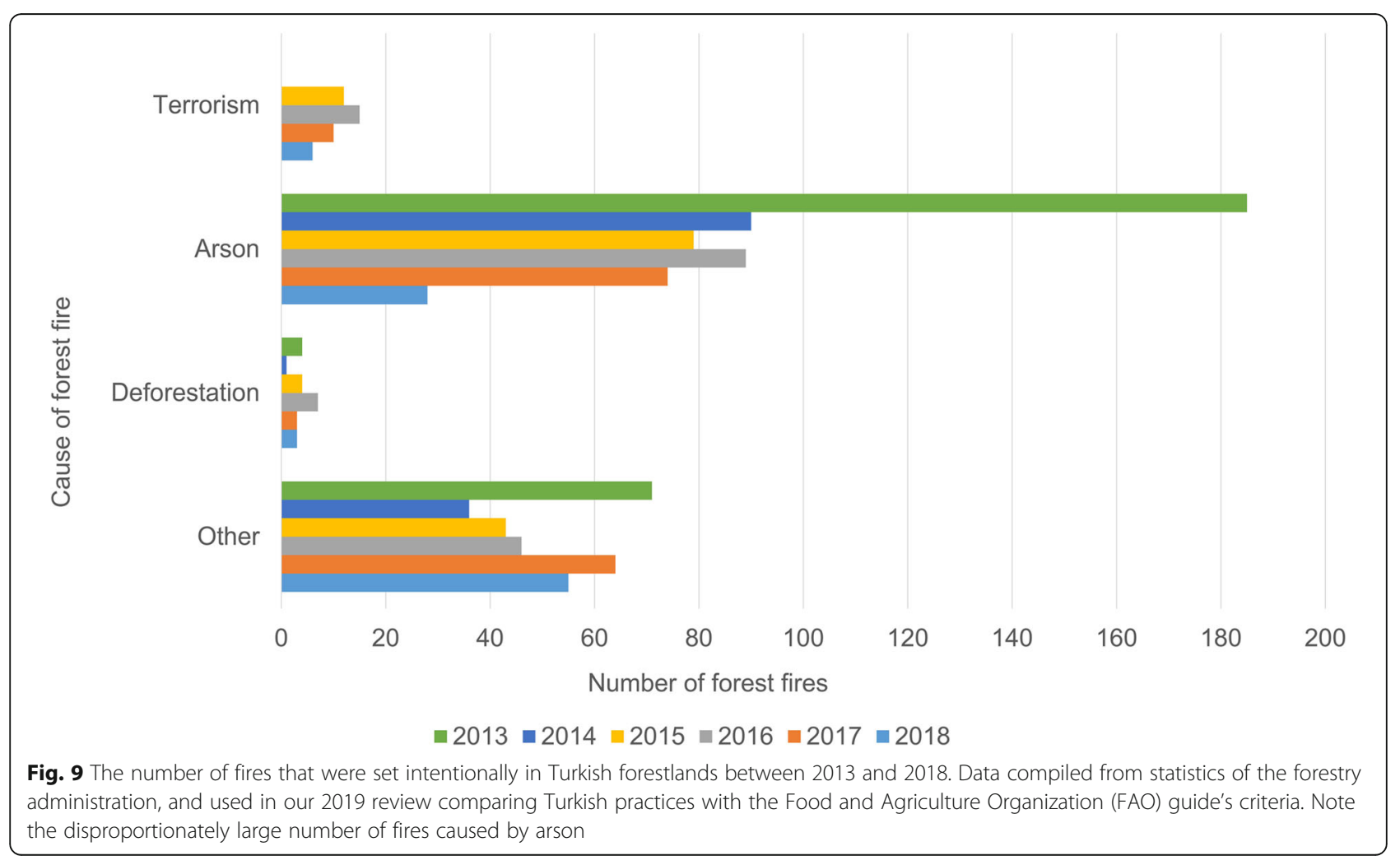


When examining legislation concerning forest fire, it is necessary to start with Article 169 of the Turkish Constitution of 1982. The first paragraph states that the State is responsible for enacting necessary laws and taking measures for the conservation and development of forestlands. It also states that burned forestlands should be reforested and that agricultural and livestock activities should not be permitted on these lands. Burned forestlands are granted constitutional security. Sensitivity to the conservation of forestlands, particularly burned ones, is clearly supported in the third paragraph of Article 169 (Ünal 2010): “... setting the forests on fire and the crimes committed for the purpose of destroying or reducing the forestlands shall not be included within the scope of any general or particular remissions." The same provisions were included in the former Turkish Constitution of 1961 in Article 131 (Ünal 2010). The most comprehensive provisions are included in Forest Law No. 6831 of 1956, which is still active. Firefighting issues and illegal acts are mentioned in Articles 68 to 76 of Forest Law (Ünal 2010). These articles cover the following provisions: making fire calls; communication and transportation facilities during fires; regulations on the participation of volunteers for firefighting; compensations to be paid to those who are injured during fires and to the relatives of those who die; regulations on the construction of surveillance towers for the purpose of fire prevention; regulations on the prevention of forest trespassing against fire hazards; and provisions that prohibit the use of flammable materials and lighting fires on forestlands.

The sanctions on forest fires are regulated in Articles 105 to 107 and 110 (Mestav 2009) of Forest Law No. 6831 as imposed by administrative and punitive fines. Those who do not report forest fires in spite of witnessing them; those who throw flammable substances on forests; and those who set forests on fire either by negligence or intentionally shall be sentenced by imprisonment, and punitive fines will be imposed on those who do not report forest fires. Administrative fines shall be imposed on those who hinder or disrupt communication and transportation during fires, and on attendants who do not fulfill given instructions during firefighting.

In addition to the aforementioned directives, a notification on "The Practice Principles of Preventing and Combating Forest Fires," No. 285 (https://www.ogm.gov. tr/ekutuphane/Tebligler/Forms/Orman_Yanginlariyla_ Mucadele.aspx), fulfills operations related to forest fires within the scope of this notification. The notification mainly focuses on the organization, action plan, and management of firefighting and extinguishing activities.

It can be clearly seen from these legislative provisions that Turkish forestry legislation has regulations related to the post-fire period that are clearly defined, and yet preventive provisions are not detailed.

\section{Results and Discussion}

Based on our analyses of forest fire legislation, we feel that effective regulations exist, with the Turkish Constitution being the foremost source of regulations. The Turkish Constitution requires reforestation of burned forestlands and excludes the crime of "setting forests on fire" from any kind of general or special remissions; these are the primary regulations that need to be emphasized. Forest fire penalties under Forest Law are especially severe and are good deterrents for arson. Another factor that increases deterrence is the punishment for committing the crime by negligence. As is stated, the crime of setting forests on fire can be included in the category of crimes with endangerment characteristics. Lighting a fire that has not caused a forest fire (Article 76b, c, and d, and Article 110 of Forest Law No. 6831) or causing a fire hazard even without the lighting of a fire (Article 76c) is considered a crime (Ünal 2010).

As for the elements of the crime and the sanctions against it, it can be concluded that some acts, related to primarily a moral element, can be considered as acts of eventual intent. It is not possible to claim negligence for forest fires that break out as a result of throwing away burning cigarettes in an area where coniferous species are dominant and dry cones and dry undergrowth exist during the summer, when the risk of inflammation is at its peak. It is possible to claim that such an act causes a forest fire by eventual intent.

As for the compensation for forest fires, only the cost of products lost from burned forests and reforestation costs are calculated and demanded as per Articles 112 and 114 of Forest Law No. 6831. No compensation is demanded for the wild animals and stray animals living in the forests in the event that they are injured. A clear provision on this issue should be made by amendment to the law, and compensation for these animals should be demanded in practice.

When data on the causes of forest fires in the last 20 years was analyzed, it was clear that $48 \%$ of fires are caused by humans. This rate rises to $71 \%$ when the rates of fires of unknown origin are included. No matter how deterrent the law is, the data illustrate that deficiency in administrative measures and lack of public awareness make combating forest fires unsuccessful. Nearly the entire budget used by the Forest Administration in combating forest fires is used for detection of forest fires and post-fire extinguishing activities. Therefore, it is necessary for the State to use all kinds of communication and education to conserve forests and prevent forest fires. The administration must frequently examine permissions and permits for forestland use, especially permissions related to power lines and dumping, and perform on-site control checks. It should be understood that the increased number of forest fires due to energy 
transmission lines, particularly in recent years, has occurred owing to a deficiency of administrative control.

As can be seen in Table 1, Turkish forestry legislation and practices have followed FAO criteria $78.1 \%$ of the time. The points that require improvement in Turkish legislation are definitions, participatory and communitybased approaches to fire management, and creating a fire line. A more detailed evaluation follows:

- Definitions: The definitions regarding forest fires aren't clear in Turkish legislation, including the Forest Law. Some necessary definitions can be found in statutes and regulations. Definitions should absolutely be regulated by law, and regulations must include the definitions. For instance, a regulation relating to issues of extinguishing forest fires must be enacted. As they stand, the regulations are legally weak and insufficient.

- Organizational Structure and Coordination among Organizations: The Turkish Forest Administration is well organized. Legislative Decree No. 3234 of 1985 (Mestav 2009), which regulates the organizational structure and duties of the General Directorate of Forestry, clearly stipulates the duties of the Department of Forest Fire Combating and its branch offices. Relevant legislation regulates the coordination among other public enterprises, as well. Therefore, sufficient legislative regulations and practices do exist in this area.

- Planning, Monitoring, and Evaluation: The Turkish Forest Administration has sufficient experience and a strong enough infrastructure to carry out the planning, monitoring, and evaluation needed to prevent forest fires. The structure and organization are regulated by Forest Law No. 6831. Therefore, the provisions in Turkish law are sufficient to meet this mentioned criterion.

- Prevention and Preparedness, Scanning, Early Warning, and Suppression: An early warning system has been installed. The system is efficient both legally and in practice in terms of detection and suppression. However, it should be noted that the prevention of forest fires is still insufficient and legal gaps exist.

- Public Participation and Social Approaches to Fire Management: The law and practice are weak in the area of participation and the social approach to fire management. In order to reduce humanmade fires, studies on participation and the social approach to fire management, including the laws in place, should be made.

- Creating a Fire Line: This criterion concerns the circumstances and methods for creating a fire line, or counterfire, as a means of fire suppression.
- Rehabilitation: Rehabilitation is one of the strengths of the current legislation. Reforestation of burned forestlands is guaranteed under the Turkish Constitution, and the Forest Law includes provisions that support the issue.

- Enforcement: Enforcement is one of the strictest measures of the Forest Law concerning forest fires. Setting fires and the other crimes defined in Forest Law No. 6831 are punishable when committed deliberately, and they are also punishable if committed by carelessness. Both the prison sentence and the fine are strong deterrents. Furthermore, claims for compensation for losses caused by forest fires can be filed, in addition to criminal lawsuits, for burned forestlands (Articles 112 and 114 of Forest Law No. 6831).

\section{Conclusion}

Turkish forest legislation is insufficient in meeting some criteria of the FAO. The most important lack is insufficient legal regulations for preventing human-made forest fires. A focus on public participation and a social approach is also lacking. A key aspect of forest firefighting is regulated only by regulations, and not laws. These regulations should be reorganized. Stipulations about definitions, participation, a social approach, and training should also be enacted into law. As is emphasized in the SWOT analysis, fire prevention training and awareness raising were the most important needs. Society's interest in nature and forestlands should be turned into an advantage, and awareness-raising activities should be given special attention. It is imperative that the administration take every measure to prevent forest fires during activities permitted on forestlands. The Forest Administration should establish a separate unit to track licenses granted for mining, dumping, and energy activities and should carry out frequent on-site audits to see whether businesses take all of the necessary precautions to prevent fires.

\footnotetext{
Acknowledgements

The authors thank the anonymous reviewers who provided valuable feedback that improved this manuscript. We also would like to acknowledge the important contributions of General Directorate of Forestry staff, without whom this manuscript could not have succeeded. Special thanks go to S. Ayanoğlu for his valuable assistance.

Authors' contributions

ODE suggested the subject and the method of manuscript and contributed to sections on legal resources in Turkish law on forest fires, analysis on Turkish forest fire legislation, analysis of Turkish legislation in terms of the FAO criteria, and the conclusions sections. ÜB was a major contributor to discussion and conclusions sections, and in writing the manuscript. UYÖ contributed to the analysis on Turkish forest fire legislation section, and the conclusions section. HTY contributed to background, the section on forest fires in Turkey, and conclusions. YÖT contributed to section on the legal resources in Turkish law on forest fires, analysis on Turkish forest fire legislation, and conclusions. All authors read and approved the final draft of manuscript.
} 


\section{Funding}

Not applicable.

\section{Availability of data and materials}

The datasets used or analyzed during the current study are available from the corresponding author on reasonable request.

\section{Declarations}

\section{Ethics approval and consent to participate}

Not applicable.

\section{Consent for publication}

Not applicable.

\section{Competing interests}

The authors declare that they have no competing interests.

\section{Author details}

${ }^{1}$ Faculty of Forestry, İstanbul University-Cerrahpaşa, Sarıyer, 34473 Istanbul, Turkey. ${ }^{2}$ Faculty of Forestry, Çankırı Karatekin University, Merkez, 18200 Çankırı, Turkey. ${ }^{3}$ Division of Justice, Şişli Vocational School, Şişli, 34398 Istanbul, Turkey.

\section{Received: 29 December 2020 Accepted: 3 April 2021}

\section{Published online: 26 April 2021}

\section{References}

Aguilar, S., and C. Montiel. 2011. The challenge of applying governance and sustainable development to wildland fire management in Southern Europe. Journal of Forestry Research 22 (4): 627-639. https://doi.org/10.1007/s11676011-0168-6.

Avcı, A., A. Čarni, S. Başaran, M.A. Başaran, P. Košir, A. Marinšek, and U. Šilc. 2010. Long-term post-fire succession of Pinus brutia forest in the east Mediterranean. International Journal of Wildland Fire 19 (5): 599-605. https:// doi.org/10.1071/WF08044.

Avcl, A., E. Örtel, I. Torres, and H. Safford. 2016. Early postfire vegetation recovery of Pinus brutia forests: effects of fire severity, prefire stand age, and aspect. Turkish Journal of Agriculture and Forestry 40: 723-736. https://doi.org/10.3 906/tar-1601-21.

Avcı, M., and K. Boz. 2017. Mersin-Gülnar ormanlarında yangın sorunu, yangınların dağıııı ve büyük yangınların değerlendirilmesi. Turkish Journal of Forestry 18 160-170. [ln Turkish.]. https://doi.org/10.18182/tjf.292769.

Ayanoğlu, S., and Y. Güneş. 2003. Orman Suçları: Ders Kitabı. İstanbul: Çantay Yayıncilık [In Turkish.].

Ayberk, H. 2000. Kuzey Kibris Türk Cumhuriyeti'nde Orman Yanginları Sorunu ve Alınması Gerekli Önlemler. Thesis. İstanbul: İstanbul Üniversitesi [In Turkish.].

Aydin Coşkun, A., and G. Gençay. 2011. Kyoto Protocol and "deforestation": A legal analysis on Turkish environment and forest legislation. Forest Policy and Economics 13 (5): 366-377. https://doi.org/10.1016/j.forpol.2011.03.013.

Bal, M., O. Ozpeynirci, and O. Yurt. 2019. International cooperation on airborne forest fire-fighting: opportunities for Turkey and Greece. International Journal of Ecology \& Development 34: 75-95.

Bayındır, S. 2016. Orman Suçları. Istanbul: Legal Yayıncılık [In Turkish.].

Boydak, M. 2004. Silvicultural characteristics and natural regeneration of Pinus brutia Ten. - a review. Plant Ecology 171 (1/2): 153-163. https://doi.org/10.1 023/B:VEGE.0000029373.54545.d2.

Çoban, H.O., and M. Eker. 2010. Analysis of forest road network conditions before and after forest fire. In FORMEC 2010, Forest Engineering: Meeting the Needs of the Society and the Environment. Citeseer, 11-14 July 2010, Padova Italy, 11-14.

Covington, W.W., and M.M. Moore. 1994. Southwestern ponderosa forest structure: changes Since Euro-American settlement. Journal of Forestry 92: 39-47. https://doi.org/10.1093/jof/92.1.39.

Elvan, O.D. 2014. Forest offences in 21st Century Turkey (with the example for the offender and trial period of illegal use of the forests in Istanbul). International Journal of Law, Crime and Justice 42: 324-1339.

Elvan, O. 2009. Orman Işgal ve Faydalanma Eylemi Üzerinde Incelemeler, Forest Engineering. Doktora Tezi, 266. İstanbul: İstanbul Üniversite, Fen Bilimleri Enstitüsü, İstanbul.
Elvan, O.D. 2013. The legal environmental risk analysis (LERA) sample of mining and the environment in Turkish legislation. Resources Policy 38 (3): 252-257. https://doi.org/10.1016/j.resourpol.2013.03.008.

Elvan, O.D., and Ü. Birben. 2021. Analysis of the Ramsar Convention's effectiveness on the Turkish legislation and judicial decisions. Wetlands 41 (3): 35. https://doi.org/10.1007/s13157-021-01435-4.

Elvan, O.D., Ü. Birben, and H.E. Ünal. 2020. The effectiveness of the Bern Convention on wildlife legislation and judicial decisions in Turkey. International Environmental Agreements: Politics, Law and Economics. https:// doi.org/10.1007/s10784-020-09498-0.

Elvan, O.D., and Y.O. Turker. 2014. Analysis of Turkish groundwater legislation and policy regarding international principles and conventions. Water Science and Technology 69 (10): 2155-2165. https://doi.org/10.2166/wst.2014.112.

FAO [Food and Agriculture Organization]. 2006. Fire management: voluntary guidelines: principles and strategic actions. In FAO Fire Management Working Paper 17. Rome: FAO.

Ganz, D., P. Moore, D. Reeb, D. Ganz, W. Hall, P. Moore, B.B. Sindangbarang, and D. Reeb. 2003. Community-based fire management case studies from China, The Gambia, Honduras, India, Lao People's Democratic Republic and Turkey. Rap Publication 2003/08, Forest Resources Development Service, Working Paper FFM/2. Bangkok: Food and Agriculture Organization of the United Nations Regional Office for Asia and the Pacific.

Gençay, G., Ü. Birben, and B. Durkaya. 2018. Effects of legal regulations on land use change: $2 / B$ applications in Turkish forest law. Journal of Sustainable Forestry 37 (8): 804-819. https://doi.org/10.1080/10549811.2018.1486717.

Günay, E. 2001. Orman ceza davaları usul ve esasları. Ankara: Seçkin Yayıncilık.

Hessburg, P.F., J.K. Agee, and J.F. Franklin. 2005. Dry forests and wildland fires of the inland Northwest USA: contrasting the landscape ecology of the presettlement and modern eras. Forest Ecology and Management 211 (1-2): 117139. https://doi.org/10.1016/j.foreco.2005.02.016.

Jaiswal, R.K. S. Mukherjee, K.D. Raju, and R. Saxena. 2002. Forest fire risk zone mapping from satellite imagery and GIS. International Journal of Applied Earth Observation and Geoinformation 4 (1): 1-10. https://doi.org/10.1016/50303-2434(02)00006-5.

Karki, S. 2002. Community involvement in and management of forest fires in South East Asia. Gland: European Commission, International Union for Conservation of Nature https://www.iucn.org/content/community-involvement-and-mana gement-forest-fires-s [...].

Küçükosmanoğlu, A., H. Ayberk, and M. Küçükosmanoğlu. 2013. Yangına hassas yerlerde, özellikle yerleşim alanları çevresinde alınabilecek yangın koruma önlemleri. Yangın ve Güvenlik Dergisi 162: 68-76 [In Turkish.].

Kucukosmanoglu, A., A.E. Bakirci, H. Ayberk, and C. Uyar. 2015. Enerji Nakil Hatları ve Orman Yangınları. In TUYAK 2015 Yangin ve Guvenlik Sempozyumu ve Sergisi. TUYAK Istanbul, Türkiye, 36-49 [In Turkish.].

Lampin-Maillet, C., M. Jappiot, M. Long, D. Morge, and J.P. Ferrier. 2009. Characterization and mapping of dwelling types for forest fire prevention. Computers, Environment and Urban Systems 33 (3): 224-232. https://doi.org/1 0.1016/j.compenvurbsys.2008.07.003.

Martínez, J., C. Vega-Garcia, and E. Chuvieco. 2009. Human-caused wildfire risk rating for prevention planning in Spain. Journal of Environmental Management 90 (2): 1241-1252. https://doi.org/10.1016/j.jenvman.2008.07.005.

Mestav, M. 2009. Orman Kanunu ve Ilgili Mevzuat. Ankara: Yayın Matbaacillik ve Ticaret Işletmesi [ln Turkish.]

MOAF [Ministry of Agriculture and Forestry] 2019. Forestry Statistics 2019, https:// www.ogm.gov.tr/tr/ormanlarimiz/resmi-istatistikler. Accessed 20 Jan 2020

MOJ [Ministry of Justice]. 2020. Judicial Statistics 2019, 250. Ankara: Ministry of Justice.

Montiel-Molina, C. 2013. Comparative assessment of wildland fire legislation and policies in the European Union: towards a fire framework directive. Forest Policy and Economics 29: 1-6. https://doi.org/10.1016/j.forpol.2012.11.006.

Morgera, E. 2010. Wildlife law and the empowerment of the poor. FAO Legislative Study 103. Rome: FAO.

Morgera, E., and M.T. Cirelli. 2009. Forest fires and the law: a guide for national drafters based on the fire management voluntary guidelines. FAO Legislative Study 99. Rome: FAO.

OGM [General Directorate of Forestry]. 2013. Orman atlası. Ankara: Orman Genel Müdürlüğü [ln Turkish.].

OGM [General Directorate of Forestry]. 2015. Annual activity report of General Directorate of Forestry (2015). Ankara: General Directorate of Forestry.

Özden, S., H. Klıı̧, H.E. Ünal, and Ü. Birben. 2012. Orman Yangını Insan Illişkisi. 1st ed. Ankara: Türkiye Ormancilar Derneği [In Turkish.]. 
Özkepir, R, and E. Küçükbiçakçi. 2019. Açıklamalı Içtihatı Orman Kanunu. Ankara: Yetkin Yayınları. [In Turkish].

Rosenbaum, K.L. 2007. Legislative drafting guide - a practitioner's view. FAO Legal Papers Online \#64, http://www.fao.org/3/bb097e/bb097e.pdf . Accessed 10 Jan 2020

Schmerbeck, J., A. Kohli, and K. Seeland. 2015. Ecosystem services and forest fires in India - Context and policy implications from a case study in Andhra Pradesh. Forest Policy and Economics 50: 337-346. https://doi.org/10.1016/j. forpol.2014.09.012.

Simorangkir, D., and G. Sumantri. 2002. A review of legal, regulatory and institutional aspects of forest and land fires in Indonesia. Jakarta: Project FireFight South East Asia.

Stephens, S.L. 2005. Forest fire causes and extent on United States Forest Service lands. International Journal of Wildland Fire 14 (3): 213-222. https://doi.org/1 0.1071/WF04006

Tedim, F., G. Xanthopoulos, and V. Leone. 2015. Forest fires in Europe: facts and challenges. In Wildfire hazards, risks and disasters, ed. J.F. Shroder and D. Paton, 77-99. Oxford: Elsevier. https://doi.org/10.1016/B978-0-12-410434-1. 00005-1.

TOD [Türkiye Ormancilar Derneği]. 2019. Türkiye Ormanciliği: 2019, 164 Ankara: TOD.

Ünal, M. 2010. Orman Hukuku. Ankara: Nobel Akademik Yayıncılık [In Turkish.].

Urker, O., C. Tavsanoglu, and B. Gurkan. 2018. Post-fire recovery of the plant community in Pinus brutia forests: active vs. indirect restoration techniques after salvage logging. iForest - Biogeosciences and. Forestry 11 (5): 635-642. https://doi.org/10.3832/ifor2645-011.

Wotawa, G., and M. Trainer. 2000. The influence of Canadian forest fires on pollutant concentrations in the United States. Science 288 (5464): 324-328. https://doi.org/10.1126/science.288.5464.324.

\section{Publisher's Note}

Springer Nature remains neutral with regard to jurisdictional claims in published maps and institutional affiliations.

\section{Submit your manuscript to a SpringerOpen ${ }^{\circ}$ journal and benefit from:}

- Convenient online submission

- Rigorous peer review

- Open access: articles freely available online

- High visibility within the field

- Retaining the copyright to your article

Submit your next manuscript at $\boldsymbol{\nabla}$ springeropen.com 